\title{
Evaluation of in vitro anticancer activity of wheat germ oil in MCF-7 breast cancer cell lines
}

\section{Buğday tohumu yağının hücrelerindeki antikanser MCF-7 meme kanseri değerlendirilmesi etkilerinin in

\author{
Mustafa Ergul ${ }^{1 *}$, Adlamu T. Bekele ${ }^{2}$, Hatice Terzi ${ }^{3}$, Ahmet Altum ${ }^{4}$
}

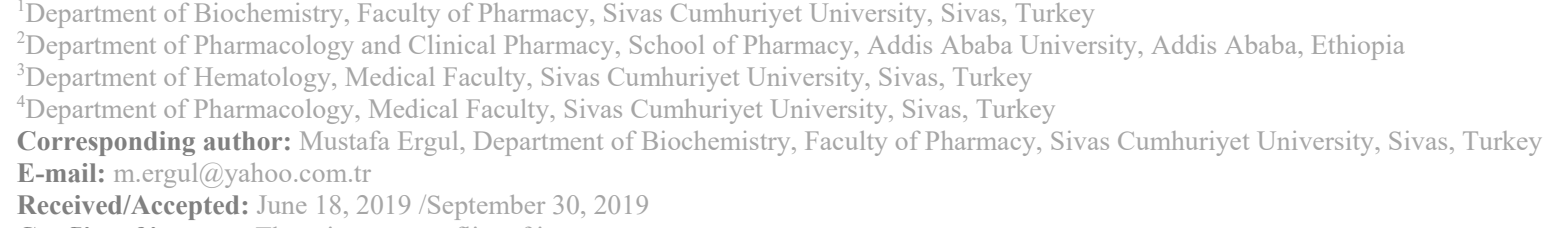

\section{SUMMARY}

Cancer is the main cause of death and morbidity worldwide. Among females, breast cancer is the most commonly diagnosed and the leading cause of cancer-related death. Despite an improvement in the treatment of cancer in the latest years, metastatic breast cancer treatment success is not at a desirable level. Plants have huge potential to endow us with noble drugs and current drugs of plant origin are important part of cancer chemotherapy. The aim of this study was to evaluate the antiproliferative activity of wheat germ oil in MCF-7 breast cancer cell line. Antiproliferative activity and apoptotic effect of wheat germ oil were examined using the XTT and flow cytometry assay, respectively. According to the XTT results, at concentrations greater than $0.5 \mathrm{mg} / \mathrm{mL}$, wheat germ oil displayed significant antiproliferative activity in MCF-7 cells in a dose-dependent manner. The Annexin $\mathrm{V}$ binding assay results also demonstrated that the $\mathrm{IC}_{50}$ concentration of wheat germ oil increased early and late apoptotic populations $(\mathrm{p}<0.05)$. Though further studies are required to specifically identify compounds involved in the anticancer activity of wheat germ oil, our findings demonstrate that wheat germ oil inhibits proliferation of MCF7 cells and its action is dose-dependent.

Keywords: Cancer, apoptosis, MCF-7, wheat germ oil

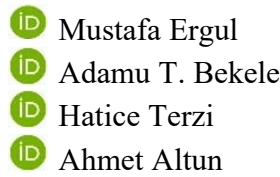

ORCID IDs of the authors: M.E. 0000-0003-4303-2996 A.T.B. $0000-0002-5772-2915$ H.T. 0000-0003-3471-1305 A.A. $0000-0003-2056-8683$

ÖZET

Kanser, dünya genelinde ölüm ve morbiditenin ana nedenidir. Kadınlar arasında meme kanseri en yaygın teşhis edilen ve kansere bağlı ölümlerin önde gelen nedenidir. Son yıllarda kanser tedavisindeki iyileşmeye rağmen, metastatik meme kanseri tedavisinde başarı oranları istenilen seviyelerde değildir. Bitkiler, yeni ilaçlar sunmak için büyük bir potansiyele sahiptir ve bitki kökenli ilaçlar halen kanser kemoterapisinin önemli bir parçasıdır. Bu çalışmanın amacı, MCF-7 meme kanseri hücre hattında, buğday tohumu yağının antiproliferatif aktivitesini değerlendirmektir. Buğday tohumu yağının antiproliferatif aktivitesi ve apoptotik etkisi sırasıyla XTT ve flow sitometri deneyleri kullanılarak araştııılmıştır. XTT sonuçlarına göre, buğday tohumu yağ1, $0.5 \mathrm{mg} / \mathrm{mL}$ 'den daha yüksek konsantrasyonlarda, MCF-7 hücrelerinde dozbağımlı bir şekilde antiproliferatif aktivite göstermiştir. Apoptoz deneyi sonuçları ayrıca, buğday tohumu yağının $\mathrm{IC}_{50}$ konsantrasyonunun erken ve geç apoptotic popülasyonları arttırdığını göstermiştir $(\mathrm{p}<0.05)$. Buğday tohumu yağının antikanser aktivitesinden sorumlu bileşiği spesifik olarak tanımlamak için daha fazla çalışma yapılması gerekli olsa da, bulgularımız buğday tohumu yağının MCF-7 hücrelerinin çoğalmasını engellediğini ve etkisinin doza-bağımlı olduğunu göstermektedir.

Anahtar sözcükler: Kanser, apoptoz, MCF-7, buğday tohumu yağ1 


\section{INTRODUCTION}

Cancer is the main cause of death and disability, with roughly 14 million new cases and eight million cancer-related deaths in 2012, affecting people in all countries ${ }^{1}$. By 2040, the number of new cases and cancer-related morbidity are expected to double when compared to the 2012 data. According to the 2016 National Vital Data Statistics report, cancer is the second biggest cause of deaths and claimed lives of approximately 600,000 persons a year in the United States ${ }^{2}$. Among females, breast cancer is the most commonly diagnosed cancer and the leading cause of cancer death ${ }^{3}$. The treatment of cancer has been improving in recent years; but yet most forms of cancers including metastatic breast cancer remain incurable and median survival of patients with metastatic breast cancer ranges from 2 to 3 years ${ }^{4}$. Despite some successes, the treatment for most cancers is still unsatisfactory, mainly because of the complexity of the disease and its causes ${ }^{5}$. Therefore, there is a constantly growing need for the development of new cancer chemotherapeutic agents and natural products are promising sources for this purpose.

Natural products have been used to treat cancer for nearly half a century, and still, they are important source of novel anticancer discovery ${ }^{6,7}$. Despite all their side-effects, drawbacks, and failures, currently, drugs of plant origin such as the vinca alkaloids, the epipodophyllotoxins, the taxanes, and the camptothecin derivatives are important part of cancer chemotherapy. Hence, plants still have huge potential to endow us with noble drugs that may provide chemotherapeutic potential against cancer? ${ }^{7}$.

Wheat germ is produced from germinating wheat and it is an important source of vitamins E and B, dietary fiber, essential amino acids, and functional phytochemicals such as flavonoids and sterols. In spite of these remarkable nutritional facts, wheat germ is seldom used for human consumption ${ }^{8}$. The possibility of using wheat germ oil (WGO) or its constituent for treatment of cancer has been reported since the 1940s, but it is tried only in few cancer cell lines. ${ }^{9}$. The aim of this study was to evaluate the antiproliferative and apoptotic activity of WGO in MCF-7 breast cancer cells. To the best of our knowledge, this is the first report to evaluate the antiproliferative and apoptotic effects of WGO on MCF-7 cell lines.

\section{MATERIAL AND METHODS}

Cell Culture and Treatment

MCF-7 (HTB-22) cell lines were bought from American Type Culture Collection (ATCC) and cultured in DMEM (Gibco Thermo Fisher Scientific) containing $10 \%$ fetal bovine serum (FBS) (Sigma-Aldrich), 1\% L-glutamine (SigmaAldrich) and 1\% penicillin/streptomycin (SigmaAldrich). The cells were maintained at $37^{\circ} \mathrm{C}$ in $5 \%$ $\mathrm{CO}_{2}$ humidified atmosphere. WGO was dissolved in DMSO and the stock solution was diluted with DMEM as the final concentration of DMSO did not exceed $0.5 \%$.

\section{Cell Viability Assay}

Cell viability was evaluated using the XTT (2,3bis-(2-methoxy-4-nitro-5-sulfophenyl)-2Htetrazolium-5-carboxanilide) colorimetric assay (Roche Diagnostic). The cells were seeded in 96well plates at a density of $1 \times 10^{4}$ cells per well in 100- $\mu \mathrm{L}$ DMEM culture media and incubated overnight before treatment. Then the cells were treated with WGO at $0.1,0.25,0.5,1$ and $2 \mathrm{mg} / \mathrm{mL}$ final concentrations for $48 \mathrm{~h}$. Following incubation, a mixture of $50-\mu \mathrm{L}$ XTT labeling solution and 100 $\mu \mathrm{L}$ DMEM without phenol red were added to all the wells and then the plates were maintained at $37^{\circ} \mathrm{C}$ for $4 \mathrm{~h}$. The plates were shaken and the absorbance was recorded using an ELISA microplate reader (Thermo) at $450 \mathrm{~nm}$. All experiments were performed three times and the cell viability was measured as viable cell amount percent compared to control, as untreated cells. The $\mathrm{IC}_{50}$ values of $\mathrm{WGO}$ in the studied cancer cell lines were calculated by Graph Prism 7 software (GraphPad).

\section{Annexin V Binding Assay}

The cells were treated with WGO at $\mathrm{IC}_{50}$ concentration and the extent of apoptosis was determined using the Muse Annexin V/Dead Cell (Merck Millipore) assay. Briefly, the cells were seeded onto six-well plates and were allowed to attach overnight before treatment. Next day, the cells were treated with $\mathrm{WGO}$ at determined $\mathrm{IC}_{50}$ concentration and incubated for $48 \mathrm{~h}$. After incubation, the cells were collected, diluted with PBS containing 1\% FBS and incubated with Annexin V \& Dead Cell reagent for $20 \mathrm{~min}$ at room temperature in dark. Live, dead, early and late apoptotic cells were analyzed by Muse Cell Analyzer (Merck Millipore).

\section{Statistical Analysis}

The statistical analysis for the assays was performed using GraphPad Prism 7.0 (GraphPad). 
Data obtained from experiments were expressed as the mean \pm standard deviation (SD) and ANOVA test with post hoc Dunnett's test was applied for versus control comparisons. All experiments were repeated three times. $\mathrm{P}$ value less than 0.05 is considered statistically significant.

\section{RESULTS and DISCUSSION}

In this study, WGO has been evaluated for its in vitro antiproliferative activity in MCF-7 cell lines.
The results of XTT assay were represented in Figure 1 and it demonstrates that WGO significantly decreased MCF-7 cell viability at concentrations greater than $0.5 \mathrm{mg} / \mathrm{mL}$ in a dosedependent manner $(\mathrm{p}<0.05)$. On the other hand, WGO did not show significant cytotoxicity to MCF-7 cells for concentrations 0.25 and 0.1 $\mathrm{mg} / \mathrm{mL}$. The $\mathrm{IC}_{50}$ value of WGO was calculated as $1.03 \mathrm{mg} / \mathrm{mL}$ for $48 \mathrm{~h}$ in MCF-7 cells.

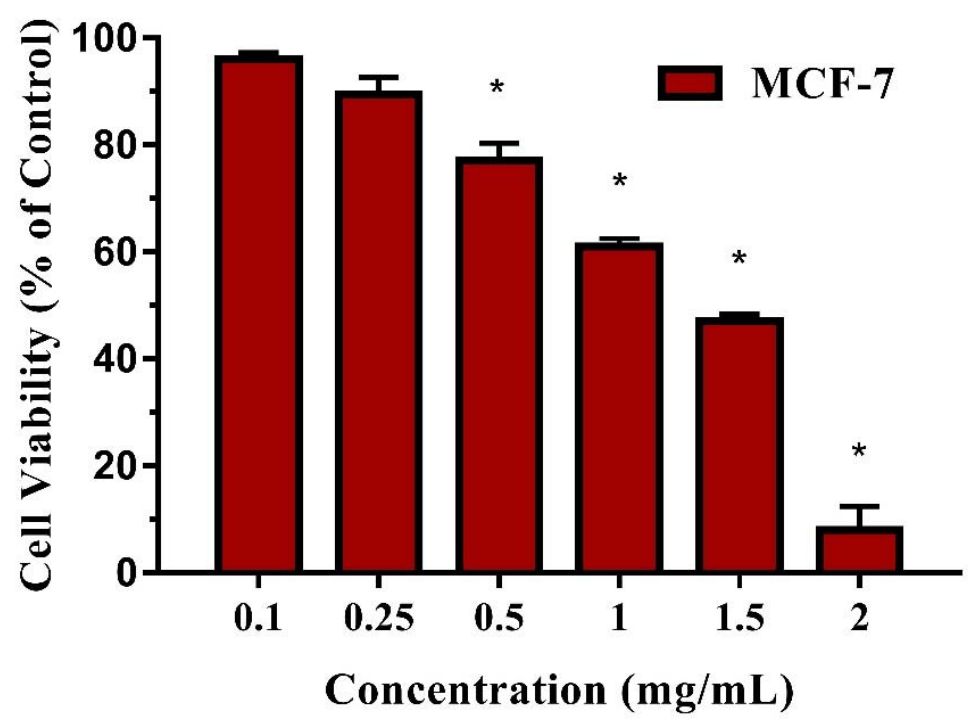

Figure 1: The antiproliferative activity of WGO on MCF-7 cell lines. The cells were treated with WGO at different concentrations $(0.1-2 \mathrm{mg} / \mathrm{mL})$ for $48 \mathrm{~h}$ and the cell viability was determined by XTT assay. All data are expressed as mean $\pm \mathrm{SD}$ in triplicate. The differences are identified as * from control $\mathrm{p}<0.05$.

Moreover, the apoptotic effects of WGO on MCF7 cells were evaluated by the annexin $\mathrm{V}$ binding analyses via flow cytometry. The results of flow analysis were illustrated in Figure 2 and it indicated that WGO showed apoptotic effect against MCF-7 cells at $\mathrm{IC}_{50}$ concentration for $48 \mathrm{~h}$ when compared to control. According to the results, the early and late apoptotic cell population $\%$ in control cells $(2.49 \pm 1.50 \%, 1.50 \pm 1.31 \%$, respectively) significantly increased to $15.00 \pm 2.09 \%$ and $8.57 \pm 0.75 \%$, respectively, in WGO treated group $(\mathrm{p}<0.05)$. 
Control

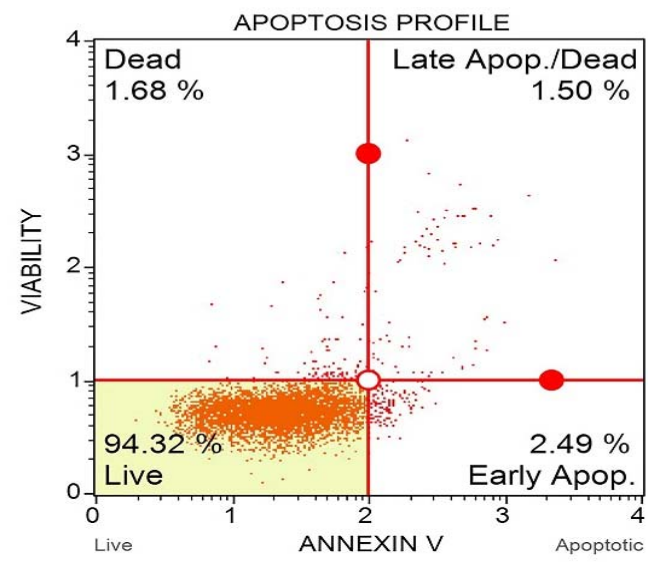

WGO

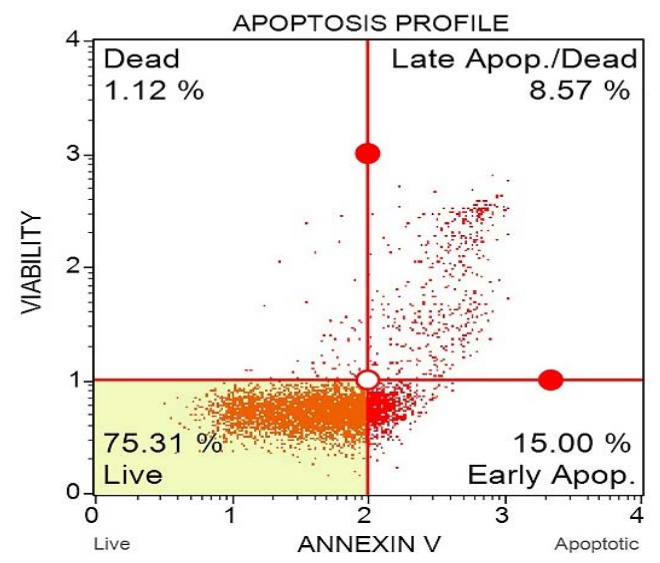

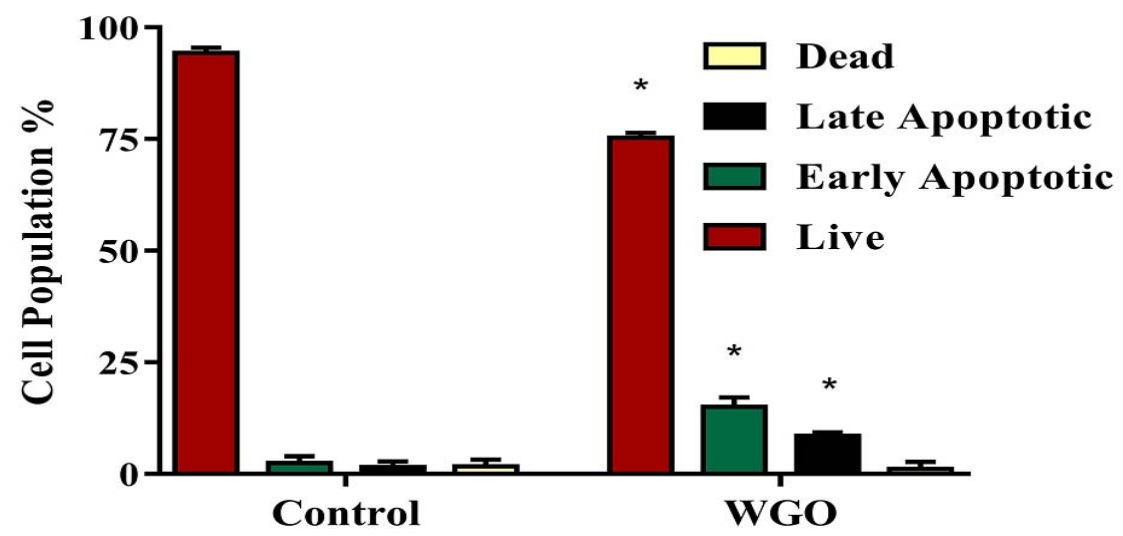

Figure 2: Annexin V binding assay results after the treatments with WGO and control. The cells were treated with the $\mathrm{IC}_{50}$ concentration of WGO and incubated for $48 \mathrm{~h}$, and the apoptosis was evaluated using the Muse cell analyzer (Millipore). Early and late apoptotic cell percentage increased significantly $(p<0.05)$ following WGO treatment. All experiments were carried out in triplicate and obtained similar results. Statistically significant differences are at $* \mathrm{p}<0.05$ compared to control.

The antiproliferative activity of WGO may be attributed to its high alpha, beta, and gammatocopherol constituent. Despite tremendous efforts to delineate the role of tocopherols in cancer proliferation, multiple studies report controversial results. Several in vitro studies reported that tocopherols and its derivatives decreased tumorigenesis in both when used alone and combined with other chemotherapeutic agents ${ }^{10-13}$. These findings go in line with our results but in others, there were no reports of appreciable treatment effect and in some cases accelerating tumorigenesis has been also reported ${ }^{14-16}$.

In the literature, there is little study related to WGO and cancer cell lines specifically in MCF-7 cells. In a recent study, Şeleci et al. investigated the anticancer activity of WGO on NIH-3T3, A-549, U87, and HeLa cell lines. Their results revealed that among these cancer cell lines, NIH-3T3 and $\mathrm{HeLa}$ cells were found to be more sensitive to WGO and at concentrations greater than 0.25 $\mathrm{mg} / \mathrm{mL} \quad$ WGO demonstrated significant antiproliferative activity. Conversely, they reported that the WGO of concentrations 0.1 $\mathrm{mg} / \mathrm{mL}$ and lower did not exhibit significant antiproliferative activity all the four cell lines. Their apoptosis assay results also showed that while WGO exhibited a moderate apoptotic effect on HeLa cells, it has no significant apoptotic effect on A549 and U87 cells ${ }^{17}$. Even though their experiment is in different cell lines, their results appear to agree with our findings in MCF-7 cells. Recently, other investigators have also found that Avemar, a derivative of fermented wheat germ extract, has several biological activities including anti-metastatic and anti-angiogenic effects. In that study, it has been shown that wheat germ extract treatment significantly decreased VEGF and Cox2 protein and mRNA levels, which are strongly related with angiogenesis and metastasis, in $\mathrm{HeLa}$ and A549 cell lines ${ }^{18}$. In a similar fashion, Fajkaboja et al. demonstrated that wheat germ extract induced apoptosis and showed antiproliferative 
effects on Jurkat leukemic $\mathrm{T}$ cells and Burkitt lymphoma B cell lines ${ }^{19}$. In another study, Judson et al. showed that wheat germ extract exhibited cytotoxic effects and increased cell sensitivity to cisplatin in ovarian cell lines ${ }^{20}$. Similarly, in a recent study Yang et al. demonstrated that wheat germ extract showed antiproliferative and antimetastatic effects on human oral squamous carcinoma SCC-4 cells. Their results also suggested that wheat germ extract treatment caused apoptosis $^{21}$. Although WGO and wheat germ extract Avamar is different, maybe WGO can also exhibit anti-metastatic and anti-angiogenic effects.

Overall, considering the studies mentioned above, WGO and wheat germ extracts significantly/moderately reduces cell viability and induces apoptosis in several types of cancer cells. The current study has demonstrated that WGO led MCF-7 cells to apoptosis due to its detrimental effect on cell proliferation.

\section{CONCLUSION}

In the present study, anticancer and apoptotic effects of WGO in MCF-7 human breast cancer cells was assessed and the results demonstrated that WGO had cytotoxic and apoptotic effect in MCF7 cells. In conclusion, this study showed the anticancer activity of WGO in MCF-7 cells suggesting that this essential oil may be further analyzed to be used for breast cancer treatment.

\section{REFERENCES}

1. Bray F, Jemal A, Grey N, et al. Global cancer transitions according to the Human Development Index (2008-2030): a population-based study. The lancet oncology. 2012;13(8):790-801.

2. $\mathrm{Xu} \mathrm{J}$, Murphy $\mathrm{SL}$, Kochanek $\mathrm{KD}$, et al. Deaths: Final data for 2016. 2018.

3. Bray F, Ferlay J, Soerjomataram I, et al. Global cancer statistics 2018: GLOBOCAN estimates of incidence and mortality worldwide for 36 cancers in 185 countries. CA: a cancer journal for clinicians. 2018;68(6):394-424.

4. Cardoso F, Costa A, Norton L, et al. 1st International consensus guidelines for advanced breast cancer (ABC 1). The Breast. 2012;21(3):242-52.

5. Chakraborty $S$, Rahman $T$. The difficulties in cancer treatment. ecancermedicalscience. 2012;6.

6. Cragg GM, Pezzuto JM. Natural products as a vital source for the discovery of cancer chemotherapeutic and chemopreventive agents. Medical Principles and Practice. 2016;25(Suppl. 2):41-59.

7. Demain AL, Vaishnav P. Natural products for cancer chemotherapy. Microbial biotechnology. 2011;4(6):687-99.

8. Sjövall $O$, Virtalaine $T$, Lapveteläinen $A$, Kallio H. Development of rancidity in wheat germ analyzed by headspace gas chromatography and sensory analysis. Journal of agricultural and food chemistry. 2000;48(8):3522-7.

9. Haddow A, Russell H. The influence of wheat germ oil in the diet on the induction of tumours in mice. The American Journal of Cancer. 1937;29(2):363-6.

10. Chamras H, Barsky SH, Ardashian A, et al. Novel interactions of vitamin $\mathrm{E}$ and estrogen in breast cancer. Nutrition and cancer. 2005;52(1):43-8.

11. Figueroa D, Asaduzzaman M, Young F. Effect of Chemotherapeutics and Tocopherols on MCF-7 Breast Adenocarcinoma and KGN Ovarian Carcinoma Cell Lines In Vitro. BioMed research international. 2019;2019.

12. Fernandes RS, Silva JO, Seabra HA, et al. $\alpha$ Tocopherol succinate loaded nano-structed lipid carriers improves antitumor activity of doxorubicin in breast cancer models in vivo. Biomedicine \& Pharmacotherapy. 2018;103:1348-54.

13. Khallouki $\mathrm{F}$, de Medina $\mathrm{P}$, Caze-Subra $\mathrm{S}$, et al. Molecular and biochemical analysis of the estrogenic and proliferative properties of vitamin E compounds. Frontiers in oncology. 2016;5:287.

14. Diao Q, Zhang J, Zhao $T$, et al. Vitamin $\mathrm{E}$ promotes breast cancer cell proliferation by reducing ROS production and p53 expression. Eur Rev Med Pharmacol Sci. 2016;20(12):2710-7.

15. Malafa MP, Neitzel LT. Vitamin E succinate promotes breast cancer tumor dormancy. Journal of Surgical Research. 2000;93(1):16370.

16. Sayin VI, Ibrahim MX, Larsson E, et al. Antioxidants accelerate lung cancer progression in mice. Science translational medicine. 2014;6(221):221ra15-ra15.

17. ŞELECİ DA, GÜMÜŞ ZP, Yavuz M, et al. A case study on in vitro investigations of the potent biological activities of wheat germ and 
black cumin seed oil. Turkish Journal of Chemistry. 2015;39(4):801-12.

18. Imir NG, Aydemir E, Şimşek E. Mechanism of the anti-angiogenic effect of avemar on tumor cells. Oncology letters. 2018;15(2):2673-8.

19. Fajka-Boja R, Hidvegi M, Shoenfeld Y, et al. Fermented wheat germ extract induces apoptosis and downregulation of major histocompatibility complex class I proteins in tumor $\mathrm{T}$ and $\mathrm{B}$ cell lines. International Journal of Oncology. 2002;20(3):563-70.
20. Judson PL, Al Sawah E, Marchion DC, et al. Characterizing the efficacy of fermented wheat germ extract against ovarian cancer and defining the genomic basis of its activity. International Journal of Gynecologic Cancer. 2012;22(6):960-7.

21. Yang M-D, Chang W-S, Tsai C-W, et al. Inhibitory effects of AVEMAR on proliferation and metastasis of oral cancer cells. Nutrition and cancer. 2016;68(3):47380 . 